\title{
Performed Substance Administration Change Reason
}

National Cancer Institute

\section{Source}

National Cancer Institute. Performed Substance Administration Change Reason. NCI

Thesaurus. Code C93969.

The rationale for chang ing the substance administration in relation to the previous substance administration. 